\title{
PERAN BAITUL MAL WA TAMWIL (BMT) TAQWA MUHAMMADIYAH DALAM MEMBEBASKAN MASYARAKAT DARI RENTENIR DI KOTA PADANG
}

\author{
Rozalinda \\ Dosen Fakultas Syariah IAIN Imam Bonjol Padang \\ roza_linda32@yaboo.com
}

\begin{abstract}
This research was intended to know any factors that influence people using usurer and how did the BMT Taqwa Muhammadiyah helped people free from usurer in Padang. This research applying descriptive qualitative technique. The finding of this research showed that people were still using usurer in overcoming their financial problems due to (1) emergency need on business assistances, (2) quick process, simple procedure and shortherm paybak periode, (3) lack of bank and non bank access (4) they do not have any information of existing BMT, (5) depleted concern on religious believe on leaving excessive interest. Moreover the finding also found that BMT Taqwa Muhammadiyab had not yet provided significant financial assistance toward vendors.
\end{abstract}

Key words: Usurer, Traditional Market, Financial Assistance, BMT

\begin{abstract}
Abstrak
Tujuan dalam artikel penelitian ini adalah, untuk mengetabui: (1) apa faktorfaktor yang menyebabkan masyarakat masib memanfaatkan jasa rentenir di Kota Padang?; (2) bagaimanakah peran BMT Taqwa Muhammadiyah dalam membebaskan masyarakat dari belenggu rentenir di Kota Padang?. Penelitian ini merupakan penelitian deskriptif kualitatif. Teknikpengumpulan data melalui wawancara, observasi dan dokumentasi. Hasil penelitian ini menunjukkan bahwa masyarakat masib menggunakan jasa rentenir dalam mengatasi masalah permodalan dikarenakan: (1) kebutuhan modal usaba maupun kebutuhan mendesak lainnya; (2) prosesnya cepat, prosedur mudah dan jangka waktu pelunasan relatif singkat; (3) sulitnya mengakses lembaga keuangan bank dan non bank; (4) kurangnya sosialisasi tentang keberadaan BMT; (5) rendabnya kesadaran keagamaan untuk meninggalkan riba. Temuan lainnya babwa BMT Taqwa Mubammadiyab belum menunjukkan berperan signifikan karena belum proaktif dalam memberikan pelayanan kepada pedagang kecil yang membutubkan modal.
\end{abstract}

Kata kunci: Rentenir, Pasar Tradisional, Bantuan Modal, BMT 


\section{Pendahuluan}

Kebijakan tentang pengembangan Lembaga Keuangan Mikro Syariah (LKMS) Baitul Maal Wat Tamwil (BMT) mempunyai posisi penting bagi perbaikan taraf hidup dan perekonomian masyarakat. Melihat kedudukannya yang cukup strategis ini, BMT diharapkan mampu menjadi pilar penyangga utama sistem ketahanan ekonomi nasional. BMT sebagai Lembaga Keuangan Mikro Syariah mempunyai peranan yang cukup besar dalam membantu kalangan usaha kecil dan menengah. Kehadiran BMT dinilai mampu menanggulangi masalah permodalan yang dialami oleh pedagang kecil mikro yang tidak dapat mengakses perbankan. Lembaga ini diharapkan berperan dalam menggairahkan usaha-usaha kecil produktif dan melepaskan masyarakat dari jeratan rentenir.

Kenyatan yang terjadi di pasar-pasar tradisional di Kota Padang, kebanyakan pedagangnya meminjam modal dari rentenir. Hal ini terjadi karena mereka kesulitan memperoleh pinjaman uang dari lembaga keuangan, terutama perbankan. Mereka terpaksa meminjam uang dari rentenir, karena renternir dianggap mampu memenuhi kebutuhan mereka dengan segera, lebih mudah persyaratannya meskipun bunganya tinggi. Di pasar ini, praktek rentenir dilakukan dalam bentuk julo-julo tembak. Banyaknya praktek rentenir di tengah masyarakat di Kota Padang mengakibatkan usaha para pedagang kecil di kota ini tidak berkembang. Sebagian besar keuntungan usahanya habis untuk membayar bunga pinjaman yang mencapai 20\%. Idealnya, keberadaan BMT dapat membebaskan masyarakat dari belenggu rentenir. Kenyataannya, para pedagang lebih senang meminjam ke rentenir karena prosesnya cepat. Jika mereka pergi ke BMT harus memenuhi persyaratan administrasi dan disurvei terlebih dahulu serta memakan waktu 3 atau 4 hari.

Salah satu fenomena yang cukup unik dan layak untuk diteliti adalah tumbuh sumburnya BMT di Kota Padang. Sejak tahun 1996 di Kota Padang telah berdiri BMT yang dipelopori oleh BMT Taqwa Muhammadiyah yang berpusat di Pasar Raya Kota Padang. BMT Taqwa Muhammadiyah Padang dibentuk atas gagasan Majelis Ekonomi Muhammadiyah Sumatera Barat. Lembaga Keuangan Mikro Syariah ini berdiri pada tanggal 29 September 1996 dengan 
modal awal sebesar Rp6.250.000,-. BMT Taqwa merupakan lembaga keuangan mikro dengan prinsip syari'ah yang berbadan Hukum Koperasi No. 33/BH/K/DK.310/IV-1999.

Yang menarik dari BMT Taqwa Muhammadiyah adalah penempatan kantor mengambil basis pasar. Pasar merupakan basis operasional para ketua julo-julo tembak (rentenir) yang menawarkan jasa financing dalam waktu yang singkat. Saat ini BMT Taqwa Muhammadiyah sudah mempunyai 4 cabang masing-masing berada di Pasar Bandar Buat, Pasar Siteba, Pasar Lubuk Buaya, Pasar Alai. Sampai November 2011, BMT Taqwa Muhammadiyah sudah melayani 9000 lebih nasabah dengan total aset 12 milyar lebih (Wawancara dengan Ismail, 21 Februari 2012). Dari latar belakang di atas, permasalahan penelitian ini difokus: (1) apa faktor-faktor yang menyebabkan masyarakat masih memanfaatkan jasa rentenir ?; (2) Bagaimana peran BMT Taqwa Muhammadiyah dalam membebaskan masyarakat dari belenggu rentenir?.

\section{Rentenir dalam Tinjauan Syari'ah}

Transaksi antara pedagang dengan rentenir tidak ubahnya seperti interaksi supply and demand dalam teori ekonomi. Rentenir menawarkan sejumlah uang (modal) yang dibutuhkan pedagang seperti yang dapat dilihat pada gambar di bawah ini:

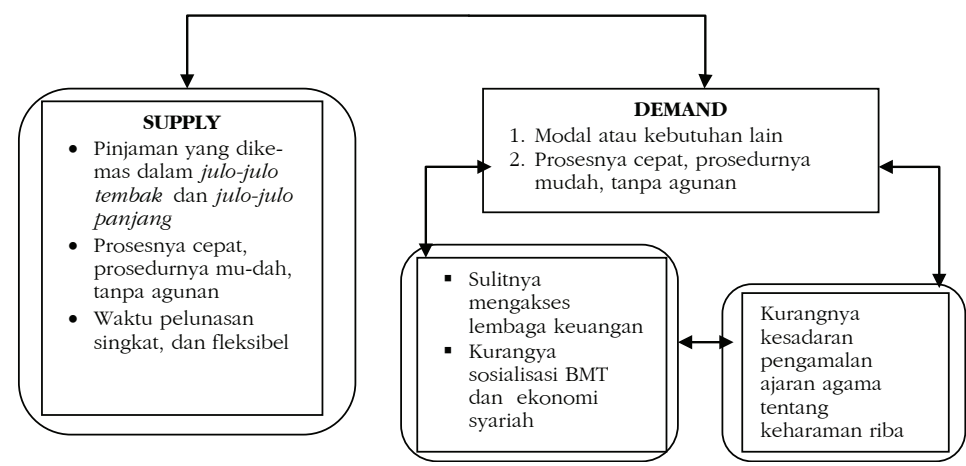

Sumber : data terolah

Gambar 1

Transaksi Rentenir di Pasar Tradisional di Kota Padang 
Kebutuhan-kebutuhan mendesak memerlukan tersedianya dana secara cepat. Hanya rentenir yang mereka anggap mampu menolong mereka di saat-saat sulit seperti itu, tidak peduli dengan bunga tinggi asalkan kebutuhannya saat itu terpenuhi. Sedangkan bank ataupun BMT hanya mampu memberikan tawaran menarik dengan serangkaian prosedur dan syarat-syarat yang justru menurut mereka berat. Dari aspek bisnis, antara rentenir yang menyalurkan uang kepada nasabahnya dengan lembaga keuangan yang menyalurkan uang kepada nasabahnya mempunyai posisi yang sama, yakni sama-sama mencari keuntungan. Perbedaannya hanya terletak pada legalitas dan akad. Rentenir menyalurkan dana dan mencari keuntungan untuk kepentingan pribadi tidak mempunyai legalitas usaha. Sementara itu, lembaga keuangan menyalurkan dana dan mencari keuntungan bukan untuk kepentingan pribadi, tetapi untuk kepentingan lembaga dan masyarakat secara bersamaan serta mempunyai legalitas usaha yang kuat.

Jika dilihat pada definisi riba yakni ziyadah yang bermakna tambahan dari modal pokok sedikit atau banyak (Sayyid Sabiq, 1983:176), maka praktek julo-julo tembak atau julo-julo panjang adalah rente. Kata rente berasal dari bahasa Belanda "rente" yang berarti bunga uang atau riba. Pelaku rente disebut dengan rentenir. Rentenir adalah orang yang secara informal memberikan pinjaman (kredit) kepada nasabah berupa uang dengan membebankan bunga yang sangat tinggi. (Tim Penyusun Kamus Pusat Pembinaan dan Pengembangan Bahasa Indonesia, 1980: 743). Bunga menurut para ulama bermakna tambahan yang dikenakan dalam transaksi pinjaman uang (al-qard) yang diperhitungkan dari pokok pinjaman tanpa mempertimbangan hasil dari modal pokok tersebut berdasarkan jangka waktu tertentu yang diperhitungkan secara pasti di muka berdasarkan persentase dari jumlah pinjaman. Rente yang dipraktikkan oleh rentenir dalam kajian fikih disebut dengan riba.

\section{BMT Sebagai Lembaga Keuangan Mikro Syariah}

Seiring dengan perkembangan penerapan sistem keuangan Islam di Indonesia, telah melahirkan lembaga keuangan mikro yang berlandaskan syariah yang dikenal dengan LKMS. Salah satu LKMS yang berkembang pesat saat ini adalah Baitul Mal wa tamwil 
(BMT). Secara legal formal, BMT sebagai lembaga keuangan mikro syariah berbentuk badan hukum koperasi. Mengacu pada peraturan pemerintah No. 9 Tahun 1995 tentang Pelaksanaan Kegiatan Simpan Pinjam oleh Koperasi, dimungkinkan koperasi menerapkan sistem imbalan dengan prinsip bagi hasil sebagaimana diterapkan di BMT. BMT mengalami perkembangan cukup signifikan dalam beberapa tahun terakhir. Bahkan, sampai tahun 2011 terdapat sebanyak 5.000 BMT di seluruh Indonesia 3.600 nya berada di bawah naungan PINBUK dengan nilai aset mencapai 3,2 triliun Rupiah (Helmi Haludin, 2012).

BMT adalah balai usaha mandiri terpadu yang berintikan bai al-mal wa al-tamwil dengan kegiatan mengembangkan usaha-usaha produktif dalam meningkatkan kualitas ekonomi pengusaha kecil. Di samping itu, BMT juga bisa menerima titipan zakat, infak, dan shadaqah, serta menyalurkannya. (Pinbuk, tt: 1) Berbeda dengan mikro finance (lembaga keuangan mikro) lainnya, BMT sebagai lembaga keungan mikro syariah memiliki keistimewaan tersendiri. Sejatinya BMT tidak hanya sebagai lembaga intermediari keuangan mikro yang berorientasi bisnis semata, BMT juga memiliki fungsi lain yang bersifat sosial.

Peran umum BMT yang dilakukan adalah melakukan pembinaan dan pendanaan yang berdasarkan sistem syariah. Sebagai lembaga keuangan syariah yang bersentuhan langsung dengan kehidupan masyarakat kecil. Keberadaan BMT mempunyai beberapa peran yakni: a) Menjauhkan masyarakat dari praktek ekonomi non syariah. Aktif melakukan sosialisasi di tengah masyarakat tentang arti penting sistem ekonomi Islami. Hal ini bisa dilakukan dengan pelatihan-pelatihan mengenai cara-cara bertransaksi yang Islami. b) Melakukan pembinaan dan pendanaan usaha kecil. BMT harus bersikap aktif menjalankan fungsi sebagai lembaga keuangan mikro, misalnya dengan jalan pendampingan, pembinaan, penyuluhan, dan pengawasan terhadap usaha- usaha nasabah atau masyarakat umum. c) Melepaskan masyarakat dari ketergantungan pada rentenir. Masyarakat yang masih tergantung renternir disebabkan renternir mampu memenuhi kebutuhan masyarakat dalam masalah pendanaan dengan segera (Zainul Arifin, 2002: 163-165). 
Ini berarti keberadaan BMT memainkan peranan yang sangat penting dalam rangka memberdayakan ekonomi masyarakat kecil dan melepaskan mereka dari jeratan rentenir. Keberadaan LKMS ini telah mampu menjadi alternatif sumber pendanaan bagi pengusaha kecil yang ada selama ini, khususnya pengusaha kecil yang bersifat informal. BMT memberikan peluang yang cukup besar bagi para pengusaha kecil sektor informal untuk mengembangkan usaha mereka.

Penelitian yang menfokuskan kajian pada peranan BMT dalam membebaskan masyarakat dari rentenir masih terhitung sedikit. Di antaranya disertasi yang ditulis Euis Amalia Reformasi Kebijakan Bagi Penguatan Peran Lembaga Keuangan Mikro Dan Usaha Kecil Mikro Di Indonesia: Analisis Keadilan Distributif Dalam Ekonomi Islam. Penelitian ini berkesimpulan bahwa reformasi kebijakan bagi penguatan peran Lembaga Keuangan Mikro (LKM) dan Usaha Kecil Mikro (UKM) di Indonesia melalui restrukturisasi alokatif adalah langkah strategis bagi pemberdayaan ekonomi rakyat sehingga keadilan distributif dapat terwujud.

Penelitian yang cukup menarik tentang microfinance berbasis syariah ditulis Asry Yusoff, Abdullah Sudin Rahman dan Moh. Noor Shapiin dengan judul: A Study on Possibility of Mosque Institution Running a Micro-Credit Programme Based on the Grameen Bank Group Lending Model: the Case of Mosque Institution in Kelantan, Malaysia. Penelitian ini menganalisis faktor faktor yang mendorong kesuksesan pengembangan lembaga keuangan mikro yang berbasis kejamaahan pada sejumlah Masjid di Kelantan Malaysia.

Ahmad Wira dalam Peluang dan Tantangan Pengembangan Lembaga Keuangan Mikro Syariah di Kota Padang. Penelitian ini meneliti tentang peluang dan tantangan pengembangan LKMS di Kota Padang. Temuan penelitian ini menunjukkan bahwa LKMS/ BMT memiliki peluang untuk berkembang karena dukungan sosial ekonomi, penguatan dan pembinaan dan dukungan dari pemerintah yang mendorong pertumbuhan Lembaga Keuangan Mikro Syariah 


\section{Metode Penelitian}

Penelitian ini merupakan penelitian deskriptif kualitatif yang berupaya mengungkap peranan BMT dalam membebaskan masyarakat dari belenggu rentenir dan mengamati faktor-faktor yang menyebabkan masyarakat masih tergantung pada rentenir. Yang menjadi sumber data dalam penelitian adalah masyarakat yang pernah terlibat dalam praktek rentenir, mulai dari ketua julo-julo sampai ke pedagang yang memanfaatkan jasa rentenir. Karena jumlah populasi tidak bisa diperkirakan maka sampel penelitian ini diambil secara snowball sampling. Di samping itu, data juga digali dari BMT Taqwa Muhammadiyah Padang.

Untuk mendapatkan data tentang fenomena rentenir dan peran BMT dalam mengatasi rentenir, penelitian ini menjaring data dengan 1) wawancara dengan rentenir, pedagang dan pihak BMT. 2) Observasi, yakni dengan memperhatikan transaksi yang dilakukan para pedagang dengan rentenir di pasar. 3) Dokumentasi tentang jumlah nasabah yang memanfaatkan jasa BMT Taqwa Muhammadiyah Kota Padang.

\section{Analisis}

Faktor-faktor yang Menyebabkan Masyarakat Memanfaatkan Jasa Rentenir

Pasar merupakan salah satu lembaga yang penting dalam institusi ekonomi. Pasar mengatur kehidupan sosial termasuk ekonomi (id.wikipedia.org: 2012). Di Kota Padang terdapat pasar yang merupakan sentral dari seluruh kegiatan transaksi dan perdagangan untuk kebutuhan masyarakat. Pasar tersebut adalah Pasar Raya Kota Padang yang merupakan pusat terjadinya fenomena ekonomi baik yang berskala besar, sedang atau kecil. Berdasarkan data dari Dinas Pasar Kota Padang tahun 2011, di Kota Padang terdapat 20 lokasi pasar baik yang dikelola pemerintah maupun nonpemerintah. Sesuai dengan batasan masalah pada penelitian ini, penelitian ini hanya menfokuskan pada pasar yang terdapat BMT Taqwa Muhammadiyah, yaitu Pasar Raya, Bandar Buat, Lubuk Buaya, dan Siteba. Berdasarkan penjelasan dari sekretaris Dinas Pasar Kota Padang, jumlah pedagang dapat dijelaskan pada tabel berikut: 
Tabel 1

Data Pedagang Toko, Kios, MB/Los dan PKL

\begin{tabular}{lccccc}
\hline \multicolumn{1}{c}{ Pasar } & Toko & Kios & MB/Los & PKL & Jumlah \\
\hline Pasar Raya & 2052 & 538 & 2272 & 2002 & 6864 \\
Lubuk Buaya & - & 160 & 222 & 225 & 607 \\
Bandar Buat & - & 144 & 319 & 195 & 658 \\
Siteba & - & 88 & 160 & 115 & 363 \\
\hline
\end{tabular}

Sumber: Dinas Pasar Kota Padang, 2011

Dari data ini, menurut sekretaris Dinas Pasar Kota Padang dapat diperkirakan jumlah pedagang ada ada di pasar-pasar tradisonal tersebut. Namun rilnya di lapangan tidak berlaku seutuhnya. Karena ada pedagang yang masuk dan keluar pasar tanpa memiliki tempat yang jelas. Praktek rentenir di pasar-pasar tradisional di Kota Padang berlaku sudah sejak lama. Bisnis ini kadang dilakoni oleh satu keluarga, kelompok ataupun individu. Misalnya di Pasar Bandar Buat, bisnis ini sudah dilakoni oleh satu keluarga secara turun temurun, sehingga peredaran uang di kalangan pedagang sudah dikuasai mereka (Wawancara dengan Fazat Rafiah, 1 Agustus 2012). Bentuk-bentuk transaksi yang biasa dilakukan oleh rentenir:

\section{Julo-julo tembak.}

Menurut Dahliar, seorang pedagang di Pasar Raya Kota Padang, julo-julo tembak merupakan bentuk perputaran uang antara ketua atau kepala julo-julo dengan masyarakat yang membutuhkan dana cepat dengan cara menerima dulu uang dari ketua julo-julo kemudian mencicilnya selama jangka waktu tertentu. Misalnya seseorang membutuhkan dana sebanyak 1.000.000,00, ketua julo-julo akan memberikan dalam waktu itu juga dengan cicilan sebanyak 30.000.00, selama 40 hari, atau 20.000,00, selama 60 hari. Artinya pinjaman 1.000.000,00, dibayar 1.200.000,00,. Pinjaman sebanyak 3.000.000,00, dibayar selama 60 hari sebesar 60.000,00 jadinya 3.600.000,00 (Wawancara, 21 Juli 2012).

2. Julo-julo panjang, atau julo julo bernomor atau julo-julo berisi. Pada julo-julo panjang, peserta diwajibkan membayar terlebih dahulu sampai jangka waktu tertentu misalnya 6 kali, bagi 
anggota yang ingin menerima uang julo-julo dicabut nomor urutnya terlebih dahulu. Seperti yang dijelaskan Ermaini seorang pedagang yang sekaligus berperan sebagai ketua julo-julo di Pasar Lubuk Buaya Kota Padang bahwa peserta membayar lepada kepala julo-julo sesuai dengan jumlah putaran ditambah satu atau dengan istilah "berkaki satu". Misalnya putaran 100 hari, cicilan 11.000,00 per hari, seorang peserta yang meminjam dana 1.000.000,00, membayar kepada ketua sebanyak 100 kali dengan cicilan 11.000,00 per hari (Wawancara dengan Ermaini, 2 Agustus 2012).

Mekanisme julo-julo tembak maupun panjang diawali dengan calon peminjam julo-julo cukup menyampaikan keinginannya untuk meminjam dana kepada ketua julo-julo. Ketua julo-julo akan memberikan pinjaman pada hari itu juga. Pinjaman bisa diperoleh sebesar Rp1.000.000.- sampai Rp5.000.000.- Pada julo-julo tembak atau panjang di pasar tradisonal di Kota Padang ini tidak mempunyai persyaratan dan prosedur tertentu. Demikian dijelaskan Nel ketua julo-julo yang membuka jaringannya di Pasar Bandar Buat Kota Padang sejak tahun 70 an. Praktik rentenir dengan kemasan julo-julo tembak atau julo-julo panjang yang berlaku di pasar-pasar tradisional di Kota Padang pada umumnya sama. Menurut Nel, sistem julo-julo tembak itu dilakukan selama 40 hari untuk orang yang belum dikenal, kalau orang itu sudah dikenal memakai 60 hari cicilan, untuk pinjaman Rp1.000.000,- dicicil selama 40 hari sebanyak Rp30.000,- per hari, kalau 60 hari cicilan dibayar sebesar Rp20.000,- per hari (Wawancara dengan Nel, 30 Juli 2012).

Untuk keterlambatan pembayaran karena alasan-alasan tertentu, pembayaran dapat digandakan pada hari berikutnya atau kekurangan pembayaran dipenuhi pada hari terakhir atau diberikan penambahan jumlah hari pembayaran dari jumlah hari yang seharusnya. Keadaan seperti ini biasanya tidak diberi sanksi seperti denda. Namun, oleh sang ketua orang tersebut masuk dalam "black list" sehingga ke depannya tidak diberi pinjaman atau tidak akan mendapat tambahan pinjaman.

Mayoritas pedagang kaki lima di pasar-pasar tradional di Kota Padang mengaku ikut julo-julo tembak maupun julo-julo panjang/ bernomor. Permintaan terhadap julo-julo tembak ini cukup tinggi. 
Dalam sehari seorang rentenir bisa memutarkan uangnya sebanyak Rp80.000.000,- (Wawancara dengan Darmalis, 21 Juli 2012).

Tingginya permintaan terhadap jasa rentenir di pasar tradisional di Kota Padang disebabkan oleh beberapa faktor sebagai berikut

1. Kebutuhan untuk modal usaha maupun kebutuhan mendesak lainnya.

Penyebab utama para pedagang meminjam uang ke rentenir adalah faktor kebutuhan terhadap modal usaha ataupun kebutuhan mendesak lainnya. Para pedagang itu meminjam dana kepada rentenir untuk berdagang. Mereka mengakui memakai julo-julo tembak adalah untuk kebutuhan modal usaha dan kebutuhan lainnya. Demikian dijelaskan War seorang pedagang yang pernah meminjam dari rentenir di Pasar Raya Kota Padang (Wawancara dengan War, 30 Juli 2012).

2. Proses pinjamannya cepat, prosedur mudah dan jangka waktu pelunasan relatif singkat.

Alasan lain pedagang meminjam dana kepada rentenir adalah karena proses pinjamannya cepat dan tanpa ada persyaratan. Caranya cukup dengan menyampaikan keinginan untuk meminjam uang kepada ketua julo-julo, seseorang segera mendapatkan pinjaman pada saat itu juga atau menunggu beberapa waktu sementara ketua julo-julo mengumpulkan uang julo-julo kepada peminjam lainnya (Wawancara dengan En, 30 Juli 2012).

Kemudahan-kemudahan tersebut menyebabkan mereka senang ke julo-julo tembak. Ini berarti bertahannya keberadaan rentenir di pasar-pasar tradisonal disebabkan karena masyarakat pedagang itu membutuhkan dana yang cepat yang tidak ada persyaratan apapun. Mereka tidak mempermasalahkan berapa bunganya, yang penting dapat dana cepat untuk tambahan modal. Seperti yang diakui Winda seorang pedagang di Pasar raya Kota Padang, di samping itu, ada kelonggaran bila tidak bisa membayar, misalnya karena sakit. Hal seperti ini tidak bisa dilakukan terhadap bank maupun BMT. Pinjaman-pinjaman yang dilakukan bersifat jangka pendek seperti bulanan, mingguan, 
bahkan harian. Pinjaman jangka pendek ini hanya bisa dilakukan dengan rentenir (Wawancara dengan Winda, 21 Juli 2012).

3. Sulitnya mengakses lembaga keuangan.

Di antara alasan mendasar mengapa para pedagang lebih suka memakai jasa rentenir adalah sulitnya mengakses lembaga keuangan termasuk BMT. Hal ini disebabkan proses dan persyaratan mendapatkan pembiayaan dari bank maupun BMT dinilai rumit, banyak persyaratan, harus survei dulu, persyaratannya banyak prosedurnya lama, uang yang diterima pun ada pemotongannya. Sementara, para pedagang umumnya membutuhkan uang cepat (Wawancara dengan Dedi Indra Yakub, 21 Juli 2012).

Proses pembiayaannya terlalu lama dan memakai agunan. Dengan rumitnya persyaratan dan prosedur mengajukan pembiayaan di bank maupun BMT, menurut Bayu Abas seorang pedagang di Pasar Siteba Kota Padang membuat pedagang akhir lari ke rentenir (Wawancara dengan Bayu Abas, 19 Juli 2012). Di samping itu, karena berdagang seharian, susah pergi ke bank. Mereka enggan meninggalkan tempat dagang untuk mengurus segala persyaratan dan datang ke BMT. Sehingga pedagang tidak mau meminjam dana ke BMT.

Bahkan pedagang yang sudah lama menjadi nasabah penabung di BMT pun mengaku karena tidak mendapatkan pembiayaan dari BMT membuat mereka akhirnya pergi ke julo-julo. Mereka juga mengaku pernah mengajukan pinjaman ke BMT, proses pinjamannya sulit, persyaratannya pun banyak. Dalam proses peminjaman perlu 3 kali pertemuan dengan pihak BMT, itu pun tidak mendapatkan pinjaman. Akhirnya, mereka meminjam ke julo-julo (Wawancara dengan Misnawati, 2 Agustus 2012).

4. Kurangnya sosialisasi tentang BMT.

Banyak pedagang kaki lima masih menggunakan jasa rentenir di pasar-pasar tradisional adalah karena belum mengetahui keberadaan BMT khususnya BMT Taqwa Muhammadiyah. Sebagian besar pedagang kaki lima di Pasar Raya Kota Padang belum mengenal sama sekali BMT Taqwa Muhammadiyah. 
Mereka tidak pernah mengajukan pinjaman ke BMT karena tidak mengetahui di mana tempatnya, bagaimana caranya, dan apa persyaratannya. Kenyataan ini tentu ini disebabkan karena kurangnya sosialisai tentang keberadaan Lembaga Keuangan Mikro Syariah yang sudah berdiri sejak 29 September 1996 ini. Dengan waktu yang sudah cukup lama, seharusnya keberadaan BMT sudah dikenal luas di kalangan pedagang di mana tempat BMT itu berada. Namun, para pedagang yang berada pada tempat yang jauh dari jangkauan BMT masih belum mengetahui keberadaan BMT itu sendiri.

Sosialisai dari pihak BMT ke nasabah tentang lembaga keuangan mikro syariah menurut Robi Andrian seorang pedagang di Pasar Siteba Kota Padang masih kurang. Kurangnya sosialisasi tentang BMT dan ekonomi syariah kepada masyarakat, menyebabkan mereka tidak mengetahui bahwa meminjam di BMT lebih ringan biayanya dari pada ke rentenir. Sehingga mereka lebih senang meminjam julo-julo tembak (Wawancara dengan Robi Andrian, 19 Juli 2012).

5. Rendahnya kesadaran pengamalan ajaran agama dalam masalah keharaman riba.

Sebagian besar pedagang memahami bahwa julo-julo tembak itu uang panas, tidak berkah, pembungaan uang. Sehingga mereka tidak ikut julo-julo tembak tersebut. Malahan ada pedagang yang memandang julo-julo tembak itu tidak halal. Mereka merasakan berdagang dengan modal melalui rentenir uangnya tidak berkah. Sebagian besar keuntungan usahanya habis untuk membayar bunga pinjaman yang besar yakni mencapai 20\%. Ia harus berhutang dan berhutang terus. Akhirnya, uang yang didapat hanya habis untuk membayar cicilan (Wawancara dengan Inun, 27 Mei 2012).

Walaupun praktek rentenir di tengah masyarakat di Kota Padang mengakibatkan usaha sebagian para pedagang kecil di kota ini tidak berkembang, uang dari julo-julo tembak adalah "uang panas". Namun, kenyataannya sebagian pedagang itu masih tetap menggantungkan modal usahanya ke rentenir. Pengetahuan dan pemahaman tersebut oleh sebagian pedagang 
pun diabaikan karena faktor kebutuhan mendesak. Menurut Fazat Rafiah, faktor pendidikan dan pemahaman agama juga memengaruhi ketergantungan para pedagang kaki lima terhadap rentenir, pada saat terdesak butuh dana cepat, mereka kembali ke julo-julo, walaupun mereka tahu bahwa di BMT lebih murah cicilannya dari pada ke rentenir. Karena faktor sangat butuh, terdesak, masalah ajaran agama mereka tinggalkan (Wawancara, 1 Agustus 2012).

Ironisnya, ketua-ketua julo-julo yang bertebaran di pasar tradisional di Kota Padang ini kebanyakan sudah menunaikan ibadah haji malah sudah berulang-ulang. Namun, bagi Kasmawati bisnis mereka bukan riba. Ia juga mengaku dirinya bukan rentenir, usahanya halal. Ia meminjamkan uang ke pedagang hanya untuk menolong (Kasmawati: 30 Juli 2012). Menurut ketua julo-julo ini, bisnisnya yang mereka jalani tersebut halal karena menolong orang yang membutuhkan modal. Mereka menjalani usaha ini dengan mengelilingi pasar, jadi wajarlah mereka meminta "belanja" dari modal yang diberikan ke pedagang dan masyarakat. Apalagi mereka juga meminjam dari bank, ada cicilan dan bunga yang harus dibayarkan. Menurut mereka, tidak mungkinlah mereka meminjamkan uang secara cuma-cuma ("maminjam anda") tanpa ada imbalan, sedangkan pedagang mendapatkan untung dari modal yang dipinjamkan. Transaksi ini dilakukan atas dasar suka sama suka. Jadi, menurutnya bisnis yang dijalankan bukan riba (Darmalis: 21 Juli 2012).

Peran BMT Taqwa Muhammadiyah dalam Membebaskan Masyarakat dari Belenggu Rentenir

Seperti yang dijelaska pada pembahasan terdahulu, pada umumnya pedagang di pasar-pasar tradisinal di Kota Padang meminjam uang kepada rentenir. Transaksi ribawi yang dikemas dalam bentuk julo-julo tembak dan julo-julo panjang ini berlaku sudah sejak lama jauh sebelum BMT berdiri.

Pembahasan tentang peran BMT dalam membebaskan masyarakat dari rentenir akan difokuskan pada proses pembiayan pada BMT, sosialisasi tentang ekonomi syariah yang dilakukan 
pihak BMT kepada masyarakat dan perannya dalam membebaskan masyarakat dari rentenir.

\section{Proses Pembiayaan di BMT Taqwa Muhammadiyah}

Upaya yang dilakukan BMT untuk membebaskan masyarakat dari rentenir adalah dalam bentuk pemberian pembiayaan. BMT menyalurkan pembiayaan ke nasabah tetap mengutamakan prinsip kehati-hatian dengan menetapkan berbagai syarat dan prosedur, di antaranya a) Ada usaha yang berada dalam kota dan sudah berjalan minimal satu tahun. b) Ada jaminan seperti BPKB, sertifikat tanah, emas, dan deposito di BMT. c) Memenuhi syarat administrasi seperti KTP, Kartu Keluarga, dan Surat Keterangan Usaha dari dinas pasar (Ismail: 25 Juli 2012).

Margin pembiayaan yang dikenakan pada BMT adalah $17-22 \%$ per tahun. besar marginnya tergantung pada jumlah pembiayaan, untuk pembiyaan di atas 5 juta marginnya $22 \%$ atau $1,75 \%$ perbulan. Jangka waktu proses pembiayaan butuh waktu 3 hari, setelah persyaratan lengkap, disurvei, kemudian rapat komite, baru dicairkan. Proses pembiayaan untuk pinjaman di atas Rp15.000.000,bisa mencapai 4 hari atau 1 minggu, apalagi pinjaman mencapai Rp50.000.000, ke atas bisa memakan waktu lebih dari seminggu. Mekanisme ini dijalani karena uang yang disalurkan adalah uang nasabah. Jadi perlu ada kehati-hatian karena itu adalah amanah. Jika nasabah yang mengulang, cicilannya yang dahulu lancar bisa dicairkan dana pembiayaan berikutnya hanya 1 hari karena tidak disurvei lagi (Ismail: 25 Juli 2012).

Sama halnya dengan bank, BMT sebagai lembaga keuangan, dalam menyalurkan pembiyaan ke masyarakat perlu memperhatikan beberapa prinsip utama yang berkaitan dengan kondisi secara keseluruhan calon penerima pembiyaan. Prinsip ini dikenal dengan prinsip 5C, yaitu character, capacity, capital. colateral, dan conditions of economy (Veitzal Rifai, 2008: 348-352). Secara garis besar, proses pemberian pembiayaan di BMT dilakukan dalam lima tahapan, yaitu: pengajuan pembiayaan, analisis pembiayaan, rapat komite pembiayaan, pengikatan pembiayaan, dan pencairan dana.

Sebagian masyarakat pedagang di pasar tradisional di Kota Padang menjadi nasabah BMT Taqwa Muhammadiyah, mereka 
menyimpan dananya di BMT dan mendapatkan pembiayaan untuk tambahan modal dagang. Proses dan prosedur pembiayaan pada BMT Taqwa Muhammadiyah menurut Robi Adrian pedagang yang pernah menerima pembiayaan dari BMT sama seperti di bank. Prosedur persyaratannya tidak sulit malah segala sesuatunya dipermudah. Namun, menurut mereka margin pembiayaannya cukup tinggi. Karena margin pembiayaan di BMT tinggi dibandingkan dengan bank umum yang juga melayani usaha mikro, banyak nasabah BMT yang mengeluh. Untuk pinjaman 10.000.000,- marginnya 20\%-22\%. Ini agak memberatkan karena marginnya terlalu tinggi (Wawancara dengan Robi Adrian, 25 Agustus 2012).

Di samping itu masyarakat pedagang di pasar tradisional ada yang hanya menjadi menjadi nasabah penabung di BMT. Menurut Eti seorang pedagang Pasar Siteba Kota Padang ia memanfaatkan jasa BMT hanya untuk menabung, untuk mendapatkan pembiayaan mereka belum pernah karena persyaratanya dan prosedurnya menurut mereka sangat rumit, di samping itu pakai jaminan dan terlebih dahulu usahanya disurvei (Wawancara dengan Eti, 22 Juli 2012).

Ada juga pedagang itu di samping memanfaatkan jasa rentenir juga menggunakan jasa BMT Taqwa Muhammadiyah untuk mendapatkan tambahan modal dagang mereka. Malahan, kepala julo-julo atau rentenir juga menjadi nasabah di BMT lembaga keuangan mikro syariah yang mempunyai misi membebaskan masyarakat dari rentenir. (Fazat Rafiah: 1 Agustus 2012) Sebagian kecil pedagang di pasar tradisonal di Kota Padang ini mengaku pernah meminjam ke BMT. Cicilan di BMT menurut mereka jauh lebih ringan dibandingkan cicilan pada rentenir, tapi karena ada keperluan mendesak akhirnya mereka kembali ke julo-julo tembak. Demikian pengakuan Arnalis seorang pedagang meminjam julojulo juga meminjam pada BMT. Meminjam ke BMT pembayarannya lebih ringan, hanya saja kadang BMT mempersulit pedagang mendapatkan pinjaman. Sedangkan julo-julo lebih memenuhi kebutuhan mendesak pedagang (Wawancara dengan Arnalis, 25 Juli 2012).

Dari kenyataan yang ada dapat disimpulkan bahwa BMT belum berperan secara signifikan dalam membebaskan masyarakat dari belenggu rentenir. Belum maksimalnya upaya yang dilakukan BMT dalam membebaskan masyarakat dari praktek rentenir yang 
cenderung lebih proaktif dalam menawarkan jasa mereka ke pedagang dibuktikan dengan banyaknya pedagang yang lebih senang berhubungan dengan para rentenir.

Menurut Juliar seorang pedagang di pasar Siteba Kota Padang ia tidak pernah mengajukan pembiayaan ke BMT karena tidak tahu proses dan prosedurnya, di samping itu juga butuh waktu untuk mengurusnya, apalagi akan meninggalkan dagangan seharian. Sehingga pedagang ini lebih suka memakai julo-julo karena proses mendapatkan dananya cepat dan tidak perlu mengurus apapun (Wawancara dengan Juliar, 22 Juli 2012) Belum maksimalnya BMT Taqwa Muhammadiyah dalam membebaskan masyarakat dari rentenir dapat dilihat dari tidak seimbangnya antara jumlah penabung yang ada dengan jumlah nasabah yang menerima pembiayaan seperti terlihat pada tabel di bawah ini:

Tabel 2

Jumlah Nasabah Penabung dan Penerima Pembiayaan Pada BMT Taqwa Muhammadiyah Kota Padang

\begin{tabular}{lcc}
\hline \multicolumn{1}{c}{ BMT Taqwa } & Nasabah & Nasabah Penerima \\
Muhammadiyah & Penabung & Pembiayaan \\
\hline Pasar Raya & 4814 orang & 296 orang \\
Pasar Bandar Buat & 2635 orang & 173 orang \\
Pasar Lubuk Buaya & 1509 orang & 201 orang \\
Pasar Siteba & 1001 orang & 148 orang \\
\hline
\end{tabular}

Sumber: BMT Taqwa Muhammadiyah tahun 2012

2. Sosialisasi tentang BMT dan Ekonomi Syariah kepada masyarakat

Upaya BMT untuk memberi penyuluhan dan sosialisai tentang BMT menurut pimpinan BMT sudah dilakukan sejak BMT berdiri baik melalui ceramah, melalui brosur, ataupun dalam bentuk mendatangi para pedagang melalui marketing BMT dengan menjelaskan BMT dan produk-produknya. Istilah BMT kurang dikenal di kalangan masyarakat pedagang. Menurut Fazat Rafiah, istilah yang muncul di tengah masyarakat adalah "Bank Taqwa Muhammadiyah", atau "Bank Muhammadiyah" atau sesuai dengan nama pimpinannya yang pertama (Wawancara dengan Fazat Rafiah, 


\section{Agustus 2012)}

Sosialisasi BMT kepada mayarakat dilakukan dengan menembus pasar dan masuk ke pedagang-pedagang kecil yang berada di pasar ini. menurut Syafri Muluk seorang pedagang sekaligus nasabah BMT Taqwa Muhammadiyah di Pasar Bandar Buat Kota Padang, sosialisasi BMT pada masyarakat adalah dalam bentuk menjelaskan BMT secara pribadi-pribadi kepada pedagang oleh petugasnya (Wawancara dengan Syafri Muluk, 30 Juli 2012). Sosialisasi BMT dan penyuluhan ke masyarakat dilakukan dalam bentuk penyuluhan tentang bagaimana pengelolaan keuangan keluarga, sosialisasi bagaimana meminjam ke BMT, apa persyaratannya, dan sebagainya. Namun, penyuluhan tentang ekonomi syariah kepada masyarakat khususnya masyarakat pedagang di pasar tradisional di Kota Padang belum dilakukan (Wawancara dengan Fazat Rafiah, 1 Agustus 2012).

BMT belum pernah melakukan penyuluhan baik kepada pedagang ataupun rentenir tentang keharaman bunga ataupun riba. Malahan mereka sudah berulang-ulang menunaikan ibadah haji. Mereka sendiri tidak mengakui bahwa bisnis dilakukan adalah rente. Malahan, mereka marah bila disebut sebagai rentenir. Alasan pembenaran dari bisnis ini adalah niat mereka hanya menolong pedagang yang kesusahan dalam masalah modal. Menurut Kasmawati pekerjaan itu memerlukan biaya, ia berjalan keliling pasar, uang yang ia putarkan berasal dari bank yang mesti dibayar bunganya (Wawancara dengan Kasmawati, 21 Juli 2012).

3. Peran BMT dalam membebaskan masyarakat dari rentenir.

Umumnya pedagang kecil atau kaki lima kekurangan modal kerja untuk menjalankan usaha, maupun memenuhi kebutuhan hidupnya. Sementara, untuk memperoleh pinjaman dari lembaga keuangan resmi seperti bank sangat sulit. Lebih jauh lagi pedagang kecil umumnya tidak mampu menyediakan jaminan bagi keperluan peminjaman. Sebagai jalan pintas, kebanyakan pedagang kecil di pasar-pasar tradisonal menjadi nasabah rentenir. Alasan peminjaman modal ke rentenir di kalangan pedagang mayoritasnya adalah karena "terpaksa" sekalipun bunganya tinggi. Kegiatan ini berlangsung secara terus-menerus hingga akhimya menjadi ketergantungan. 
Meski demikian, kebanyakan pedagang pengguna jasa rentenir di Kota Padang ini mengaku tidak terlalu dirugikan dengan keberadaan rentenir.

Pada umumnya pedagang kaki lima di pasar tradisional memakai jasa rentenir dalam menanggulangi masalah permodalan mereka. Dari jumlah pedagang yang ada di Pasar Bandar Buat, menurut Fazat Rafiah, 70\% memakai jasa rentenir. Setelah ada BMT sekitar 40\% menurut pimpinan BMT ini bisa lepas dari rentenir dengan menjadi nasabah BMT. Walaupun mereka bolak-balik ke rentenir dan ke BMT, malahan menggandakan keduanya. Upaya yang dilakukan BMT dalam membebaskan masyarakat dari rentenir adalah menawarkan pembiayaan dengan persyaratan dan prosedur dari BMT dengan tidak seperti standar perbankan (Wawancara dengan Fazat Rafiah: 1 Agustus 2012).

Dalam memberdayakan ekonomi masyarakat BMT berupaya menyalurkan pembiayaan untuk menambah modal usaha kepada pedagang. Yakni kepada pedagang yang mempunyai usaha lebih dari satu tahun, mempunyai omset yang jelas dan tempat yang tetap. Pinjaman awal Rp5.000.000, kemudian bisa berlanjut mendapatkan pinjaman Rp10.000.000,-. Bagi nasabah yang mengulang, dana bisa dicairkan dalam satu hari, apabila pembiayaan yang terdahulu lancar, karena tidak perlu disurvei lagi (Wawancara dengan Ismail, 25 Juli 2012).

Berdasarkan kenyataan ini dapat disimpulkan, upaya BMT dalam mengemban tugas membebaskan masyarakat dari praktek ekonomi ribawi belum maksimal. BMT belum proaktif dalam memenuhi kebutuhan pedagang yang kesulitan dalam masalah permodalan. BMT kalah cepat dalam menawarkan jasa dan produknya ke pedagang dalam upaya meminimalisir jeratan rentenir kepada pedagang. Di pihak lain, rentenir lebih proaktif dalam menawarkan jasa kepada pedagang yang kesulitan dalam modal. Para rentenir terus berjalan mengelilingi pasar seperti "bank keliling", karena mereka mengetahui dengan persis apa yang dibutuhkan pedagang.

Konsep BMT sebagai lembaga keuangan mikro syari'ah, merupakan konsep pengelolaan dana (simpan-pinjam) di tingkat 
komunitas yang terendah yaitu pedagang kecil khusunya pedagang kaki lima. Untuk mencapai hal itu BMT melakukan gebrakan dengan 1) Aktif melakukan sosialisasi di tengah masyarakat tentang arti penting sistem ekonomi Islami. 2) Memberikan kemudahan proses dan pesyaratan pembiayaan kepada nasabah sesuai dengan penilaian kelayakan. 3) Memperkuat lembaga dengan karakter "jemput bola".

\section{Kesimpulan}

BMT Taqwa Muhamaddiyah yang mengambil basis pasar tradisonal di Kota Padang ini sudah lama berdiri, namun masyarakat sampai hari ini masih menggunakan jasa rentenir dalam mengatasi masalah permodalan mereka. Hal ini disebabkan karena: Pertama, kebutuhan untuk modal usaha maupun kebutuhan mendesak lainnya. Kedua, proses pinjamannya cepat, prosedurnya mudah dan jangka waktu pelunasan relatif singkat. Ketiga, sulitnya mengakses lembaga keuangan termasuk BMT. Keempat, kurangnya sosialisasi tentang BMT. Kelima, rendahnya kesadaran pengamalan ajaran agama dalam masalah keharaman riba.

Sementara itu, BMT Taqwa Muhammadiyah sebagai Lembaga Keuangan Mikro Syariah yang mempunyai misi membebaskan masyarakat dari ekonomi ribawi belum meunjukkan peran yang signifikan, karena lembaga ini belum bersikap proaktif dalam memenuhi kebutuhan pedagang kecil terhadap permodalan mereka. Hal ini dibuktikan dengan masih sedikitnya jumlah pedagang yang memperoleh pembiayaan dari lembaga keuangan mikro syariah tersebut.

Diharapkan kepada pengelola BMT untuk lebih bersikap proaktif dalam memenuhi kebutuhan masyarakat dalam hal permodalan, sehingga ketergantungan terhadap rentenir bisa diminalisir. Kepada para mubaligh diharapkan untuk lebih sering memberikan pencerahan dan penyadaran kepada masyarakat tentang keharaman ekonomi ribawi. Kepada pemerintah diharapkan untuk memberikan kemudahan kepada pedagang kecil untuk mengakses kredit usaha rakyat (KUR). 


\section{Daftar Pustaka}

Arifin, Zainul. 2002. Dasar-dasar Manajemen Bank Syariah, Jakarta: Alvabet.

al-Baihaqi, Abu Bakar Ahmad ibn al-Husain ibn Ali. 1344 H. Sunan al-Baihaqi. tp: Majelis Dairah al-Maarif al-Nizhamiyah alKainah.

al-Juzairi, Abdurrahman. 1969. al-Fiqh Ala Mazahib al-Arba'ah, Juz III, Mesir: al-Maktabah al-Tijariyah al-Kubra.

Haludin, Helmi. 2012. "Membangkit Kearifan Lokal dalam Pemberdayaan Ekonomi Syariah, Makalah disampaikan pada Silakda dan Seminar Majelis Pengurus Ikatan Cendekiawan Indonesia (ICMI) Organisasi Daerah Kota Padang.

http://www.pikiranrakyat.com/cetak/2005/1005/09/hikmah/ manajemen.html, 17 Agustus 2006.

PINBUK. t.t. Pedoman Cara Pembentukan BMT Balai Usaha Mandiri Terpadu, Jakarta: PINBUK.

Sabiq, Sayyid.1983. Fiqh as-Sunnah, Juz III. Libanon: Dar al-Fikr. Sudarsono, Heri. 2003. Bank dan Lembaga Keuangan Syari'ah. Jakarta: Kampus Fakultas Ekonomi UUI.

Tim Penyusun Kamus Pusat Pembinaan dan Pengembangan Bahasa Indonesia. 1990. Kamus Besar Bahasa Indonesia. Jakarta: Balai Pustaka.

\section{Responden:}

Agus Fitri, Account Officer BMT Taqwa Muhammadiyah cab Pasar Lubuk Buaya, wawancara, 2 Agus 2012

Anto, pedagang, wawancara, Pasar Raya, 27 Mei 2012

Bayu Abbas, pedagang, nasabah BMT, wawancara, Pasar Siteba, 19 Juli 2012

Dahliar, pedagang, wawancara, Pasar Raya, 21 Juli 2012,

Darmalis, ketua julo-julo, wawancara, Pasar Raya, 21 Juli 2012

Dedi Indra Yakub, ketua julo-julo, wawancara, Pasar Raya, 21 Juli 2012

Epa, pedagang, ketua julo-julo, wawancara, Pasar Siteba, 22 Juli 2012. 